\title{
Invasive Mesquite (Prosopis juliflora), an Allergy and Health Challenge
}

\author{
M. Iftikhar Hussain 1,2,*(D), Ross T. Shackleton ${ }^{3,4}\left(\mathbb{D}\right.$, Ali El-Keblawy ${ }^{5}$ (D), \\ María Del Mar Trigo Pérez ${ }^{6}$ and Luís González ${ }^{2}$ (D)
}

1 Research Institute of Science and Engineering, University of Sharjah, P.O. Box 27272, Sharjah 2141, UAE

2 Plant Biology \& Soil Science Department, Universidad de Vigo, 36310-Vigo (Pontevedra), Spain; luis@uvigo.es

3 Centre for Invasion Biology, Department of Botany and Zoology, Natural Sciences Building, Private Bag X1, Stellenbosch University, Matieland 7600, South Africa; rtshackleton@gmail.com

4 Institute of Geography and Sustainability, University of Lausanne, 1015 Lausanne, Switzerland

5 Department of Applied Biology, College of Sciences, University of Sharjah, P.O. Box 27272, Sharjah 2141, UAE; akeblawy@sharjah.ac.ae

6 Departamento de Biologia Vegetal, Universidad de Málaga, PO Box 59, 29080 Malaga, Spain; aerox@uma.es

* Correspondence: mih786@gmail.com or miftikhar@sharjah.ac.ae; Tel.: +971-5-6786-0330

Received: 6 November 2019; Accepted: 11 December 2019; Published: 22 January 2020

\begin{abstract}
Mesquite (Prosopis juliflora (Sw.) DC), is an medium-sized tree (family Fabaceae, subfamily Mimosoideae), that has been intorcuded around the world. It is a noxious invasive species in Africa, Asia, and the Arabian Peninsula and a source of highly allergenic pollen in. The present article reviews the adverse allergenic effects of $P$. juliflora pollen on human and animal health. Several studies have diagnosed that allergenic pollens from Prosopis spp. can provoke respiratory problems. Prosopis pollen extracts have 16 allergenic components of which nine proteins were recognized as major allergens with some of them showing cross-reactivity. Clinically, understanding Prosopis pollen production, flowering seasonality, pollen load, and dispersal in the atmosphere are important to avoid allergic consequences for local inhabitants. Climate change and other pollution can also help to further facilitate allergenic issues. Furthermore, we document other human and animal health problems caused by invasive Prosopis trees. This includes flesh injuries, dental and gastric problems, and the facilitation of malaria. This review summarizes and enhances the existing knowledge about Prosopis flowering phenology, aeroallergen, and other human and animal health risks associated with this noxious plant.
\end{abstract}

Keywords: allergy; allergens; biological invasions; human heath; human well-being; pollens; prosopis; immunology; impact; invasive alien tree; invasive species

\section{Introduction}

Many human activities, such as agriculture, recreation, global trade, and transportation have promoted both the intentional and accidental spread of species across their natural dispersal barriers [1,2]. A number of introduced species establish and spread becoming invasive in their new habitats, and can become serious ecological and health risks [3]. In particular, many invasive alien plant species have negative impacts on human and animal health and wellbeing through allergens, toxicity, and by causing injuries [4-7]. Understanding and documenting these effects on health are crucial to support management initiatives to reduce impacts. One such invasive alien genus that has serious human and animal health threats is Prosopis spp.

Prosopis L. is a genus with 44 species of medium-sized trees and shrubs belonging to family Fabaceae, subfamily Mimosoideae, with species occurring naturally in Africa, Asia, and North and 
South America [8]. Prosopis was found to occur as native or introduced species in 129 countries globally primarily in the world's hot arid and semi-arid regions [6]. The numerous goods and services provided by Prosopis have led to global introductions and have made some species important for local communities [6,9]. At least 19 (invasive and weedy) of the 44 species in the genus Prosopis are known to generate benefits and costs in their introduced and invasive ranges, with the rest being primarily beneficial in their native ranges [6]. A particularly invasive species, Prosopis juliflora, has become widespread in many parts of the world. Prosopis juliflora is a fast-growing tree (5-10 $\mathrm{m})$, native to frost-free tropical regions of Peru, Central America, and the Caribbean. It has long lateral shallow and deep taproot systems that are also able to fix nitrogen $[6,8]$. It has been introduced to different parts of the world for different purposes, but it has become an aggressive invader in most introduced ranges. Prosopis juliflora is now one of the most prominent of the invasive species from the genera, commonly invasding countries in Africa, the Middle East, and Asia, along with Prosopis glandulosa, Prosopis velutina and their hybrids in South Africa and Australia [6]. For example, it was introduced to Sudan in 1917 to combat desertification and to provide fuelwood [10]. Similarly, this species was brought to Lake Baringo, Kenya, in the 1980s to alleviate the fuelwood shortage [11,12]. In India, it was introduced during the late nineteenth century for the rehabilitation of sodic lands and to supply of fuelwood, fodder, timber, and fiber [13] and into Ethiopia in the 1970s and 1980s mainly for soil and water conservation [14]. This study, focus particularly on P. juliflora although the negative impacts mentioned here do occur for other invasive Prosopis species as well.This review examines current knowledge about the allergenic impact of $P$. juliflora on humans and associates it with the trees flowering phenology, pollen production, release, as well as other human and livestock health risks caused by the trees other traits, particularly, focusing on evidence from Africa and the Middle East. The review also highlights Prosopis aeroallergens, cross-reactivity, and its correlation with climate change consequences.

\section{History of P. juliflora in African and Arabian Peninsula}

The history and range of distribution of the invasive Prosopis has been covered by several authors [15-19]. It is particularly prevalent as an invasive in Ethiopia, Kenya, Sudan, and South Africa [6]. According to Pasiecznik et al. [9], the P. juliflora, P. pallida complex, has been recorded in most of the African countries. However, P. juliflora is frost sensitive and severe frost can cause tree mortality in countries with cooler weather. Consequently, there is a doubt about the presence of this species in the Mediterranean climates of countries such as Morocco, Algeria, Tunisia, Libya, and Egypt. Similarly, Akrimi [18] stated that cold-sensitive P. juliflora was killed outright in Tunisia. Most of the Prosopis species that are present in these countries are more likely to be P. glandulosa Torr., P. velutina Wooton, P. chilensis (Molina) Stuntz, or hybrid forms from these species [8].

Prosopis juliflora has typically invaded areas in Africa and the Arabian Peninsula where water table is close to the ground surface, such as gravel deserts, open plains, sand sheets, rivers and flood plains, wadies, and edges of farms [19-22]. In Saudi Arabia, P. juliflora was reported as a ruderal plant, mostly found inside the urban and suburban areas but also other natural areas on the mainlands and islands of the region and is the most prominent invasive species in majority of lowlands [22]. Prosopis juliflora was introduced to the UAE in the 1970s for greening deserts [19,20,23]. During the last four decades, this species has escaped the planted forests and is currently considered a serious weed [23]. It has been reported in many natural habitats of UAE that have shallow water tables as well as in productive farmlands (Ali El-Keblawy, unpublished data). In Bahrain, scattered patches of young $P$. juliflora plants were recorded on coastal lowland, along with a huge single tree (said to be more than 500 years old and with more than $30 \mathrm{~m}$ tall) in the central plateau of the island. Similarly, this species was introduced to Qatar during the 1950s and it grows around farmland as well as in depressions [24]. 


\section{Adverse Health Impacts of Prosopis in Humans}

Prosopis invasions have a number of negative effects on human and animal health which impacts well-being and local livelihoods $[4,6,7]$. With regards to human health, there are evidences that Prosopis is inducing serious allergic reactions, even leading to septicemia. Furthermore, Prosopis can cause skin septicemia from thorn injuries and leads to an increased prevalence of malaria [24,25]. With regards to animal health, especially livestock, Prosopis is known to result in flesh injuries, and has negative gastro internal, neurological, as well as dental impacts which can make animals sick and even lead to death. We discuss this in more detail below.

\section{Prosopis Pollen, Allergy and Impact}

Airborne Prosopis pollen grains are common where the tree is present and is a source of allergy reactions (pollinosis, rhinitis, conjunctivitis, asthma) in both its native and invasive range (Figure 1) [25]. Human sensitization to Prosopis was unveiled as early as the 1950s thanks to previous studies carried out by Ordman [26], Bieberdord and Swinny [27], Shivpuri and Parkash [28], Novey et al. [29], Thakur [30], and Lucas and Buckley [31], among others. Issues of allergies have also been reported for example, in the southwestern United States [29], in several regions of India [32], Pakistan [33], Saudi Arabia [34], South Africa [35,36], and a number of countries in the Neotropics/South America [37].
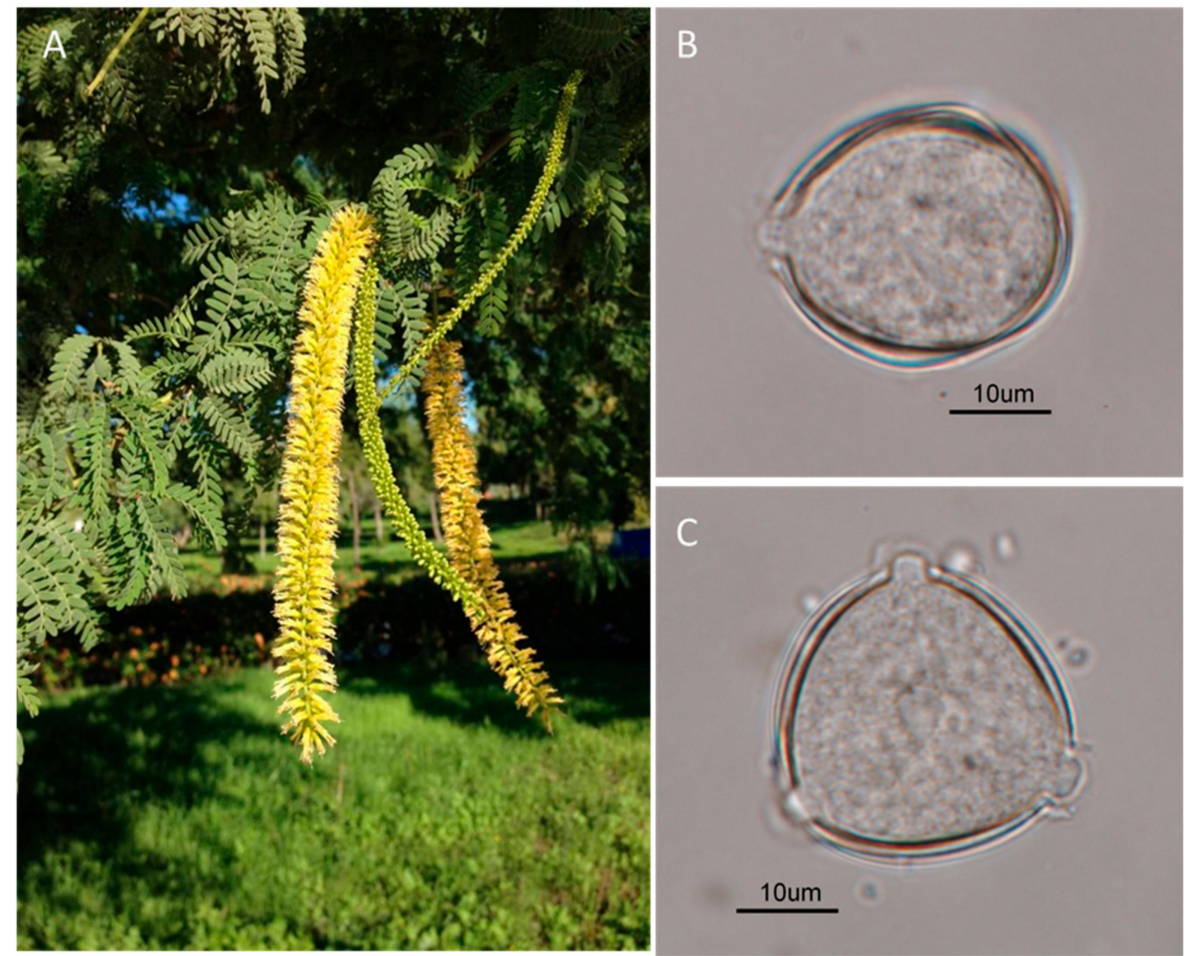

Figure 1. P. juliflora: plant showing the inflorescences (A) and pollen grains, equatorial (B) and polar (C) view, (light microscope, $\times 400$, scale bar $10 \mu \mathrm{m}$ ).

In the Middle East, Prosopis has been recognized as a major cause of allergic disease for some time, such as, in the Saudi Arabia [34,38], Kuwait [39], and United Arab Emirates [40], and high densities of invasion in urban areas exacerbate this [41]. Lab studies have concluded that Prosopis pollen is a serious threat to human health and has at least 13 different allergenic fractions [40]. In the UAE, about 45\% of people tested were sensitive to Prosopis pollen (Figure 1) [29]. Al-Frayh et al. [34], studied the incidence of P. juliflora pollen in the population of four localities (Abha, Qassim, Hofuf, and Gizan) in Saudi Arabia by means of skin prick test and Radio allergosorbent-Test (RAST), for immediate hypersensitivity reaction to Prosopis allergens. Their results showed that $76.1 \%$ of patients in Qassim, 
37.5\% in Gizan, $29 \%$ in Abha, and $11 \%$ in Hofuf reacted positively to Prosopis antigens. Hight levels of Prosopis pollen grains were detected around Gizan,, exceeding 90 grains $\mathrm{m}^{-3}$ of air [34].

Al-Soqeer et al. [42], showed that 18 different allergen proteins and eight biogenic amines were detected in fifty P. juliflora genotypes collected from two regions of Saudi Arabia with different environmental conditions. The proteins had molecular weight ranging from 14 to $97 \mathrm{kDa}$. A list of different $P$. juliflora amine concentrations from the a-Qassim region of Saudi Arabia is demonstrated in Table 1, hilighting high levels of different allergy causing molecules for this invasie tree, but also veriations acorss different genotypes. Interestingly, they concluded from this study that environmental conditions, especially humidity, did not have any effect on allergen protein or their bioamine contents [42]. The impact of P. juliflora pollen extract was evaluated on respiratory allergy patients from Bikaner and Delhi, and it was found that Prosopis extract elicited positive skin reactions in 71 of the 220 patients [43]. They demonstrated the presence of 16 Immunoglobulin E (IgE) binding components in patient sera ranging from $24-95 \mathrm{kDa}$. Using gel filtration chromatography and polyacrylamide gel electrophoresis with 7.5\% gels, Thakur and Sharma [44], separated P. juliflora into six fractions of 13, 20, $27.5,41,55.5$, and $81 \mathrm{kd}$, and it was found that the $20 \mathrm{kd}$ fraction had the highestallergenic activity.

Table 1. The list of amine concentrations in Prosopis juliflora genotypes from the Al-Qassim region, Saudi Arabia (Source: Al-Soqeer et al. [42]).

\begin{tabular}{|c|c|c|c|c|c|c|c|c|}
\hline Genotypes & $\begin{array}{c}\text { Tryptamine } \\
(\mu \mathrm{g} / \mathrm{g})\end{array}$ & $\begin{array}{l}\beta \text {-phenylethy- } \\
\text { lamine }(\mu \mathrm{g} / \mathrm{g})\end{array}$ & $\begin{array}{c}\text { Putrescine } \\
(\mu \mathrm{g} / \mathrm{g})\end{array}$ & $\begin{array}{c}\text { Cadaverine } \\
(\mu \mathrm{g} / \mathrm{g})\end{array}$ & $\begin{array}{l}\text { Histamine } \\
(\mu \mathrm{g} / \mathrm{g})\end{array}$ & $\begin{array}{c}\text { Tyramine } \\
(\mu \mathrm{g} / \mathrm{g})\end{array}$ & $\begin{array}{l}\text { Spermidine } \\
(\mu \mathrm{g} / \mathrm{g})\end{array}$ & $\begin{array}{c}\text { Spermine } \\
(\mu \mathrm{g} / \mathrm{g})\end{array}$ \\
\hline B1 & 54.4 & 45.6 & 45.6 & 7.4 & 18.6 & 132.2 & 17.5 & 4.4 \\
\hline B2 & 45.2 & 12.1 & 25.7 & 5.2 & 4.7 & 55.6 & 7.5 & 3.9 \\
\hline B3 & 83.3 & 47 & 126.3 & 79.5 & 37 & 396.2 & 49.5 & 7.4 \\
\hline B4 & 27.5 & 21.3 & 19.6 & 5.5 & 6.6 & 55.2 & 6.6 & 2.7 \\
\hline B5 & 61.5 & 38.3 & 66.2 & 9 & 17.7 & 174.1 & 24.8 & 5.6 \\
\hline B6 & 60.5 & 26 & 46.5 & 7.2 & 9.4 & 90.4 & 16.5 & 7.2 \\
\hline B7 & 11.4 & 4.3 & 5.5 & 10.3 & 1.3 & 13.7 & 1.6 & 0.2 \\
\hline B8 & 22 & 41.2 & 17.1 & 33.1 & 9.6 & 205.2 & 9 & 1.8 \\
\hline B9 & 35 & 36.8 & 98.6 & 4.6 & 30.2 & 154.1 & 92.5 & 30 \\
\hline B10 & 53.3 & 41.9 & 39.9 & 183.8 & 9.2 & 198.2 & 25.1 & 15.9 \\
\hline B11 & 24.1 & 15 & 18 & 4.8 & 8.3 & 63 & 4.4 & 1 \\
\hline B12 & 20.6 & 35.2 & 22.4 & 16.2 & 2.9 & 232 & 17.3 & 11.9 \\
\hline B13 & 37.5 & 34.2 & 39.8 & 7.4 & 9.2 & 191 & 24.7 & 6.9 \\
\hline B14 & 61.7 & 25.1 & 75.1 & 31 & 19.3 & 198.2 & 30.1 & 11.1 \\
\hline B15 & 46.7 & 40.5 & 63.7 & 39 & 7.7 & 224.6 & 45.5 & 12.4 \\
\hline B16 & 37.8 & 33.2 & 58.1 & 4.5 & 10.1 & 235.7 & 34.8 & 16.9 \\
\hline B17 & 28.1 & 20.8 & 54.3 & 77.7 & 11 & 213.1 & 36.9 & 15.7 \\
\hline B18 & 25.2 & 22.1 & 20.5 & 88.3 & 12.5 & 190 & 9.8 & 5.2 \\
\hline B19 & 27 & 21.8 & 32.5 & 93.6 & 15.5 & 247 & 22.5 & 13.5 \\
\hline B20 & 34.8 & 16.7 & 42.4 & 16.9 & 4.1 & 108.2 & 32.4 & 16.4 \\
\hline B21 & 40.8 & 11.7 & 24.8 & 6.7 & 7.9 & 112.6 & 6.8 & 6.5 \\
\hline B22 & 75.1 & 27.1 & 59.9 & 21.7 & 17.2 & 99.2 & 22.1 & 5.6 \\
\hline B23 & 9.1 & 4.6 & 6 & 0.83 & 0.9 & 25.9 & 3 & 4.1 \\
\hline B24 & 39.6 & 41.4 & 52.3 & 6.5 & 10.1 & 218 & 31.5 & 17 \\
\hline B25 & 12.6 & 6.2 & 13.9 & 4.6 & 4.3 & 58 & 8.1 & 5 \\
\hline S.E.* & \pm 3.9 & \pm 3.1 & \pm 5 & \pm 8.6 & \pm 1.8 & \pm 17.4 & \pm 3.9 & \pm 1.3 \\
\hline
\end{tabular}

S.E. ${ }^{*}=$ Standard Error; difference between two means $\geq$ SE indicates significant difference.

Cross-racctivity an be a big issues regarding plant pollens. Cross-reactivity relates to the reaction between an antibody and an antigen that differs from the immunogen. The accurate knowledge about the cross-reactivity of $P$. juliflora pollen is crucial for diagnostics and the formulation of adequate immunotherapy. Cross-reactivity of $P$. juliflora pollen with other plants willfurther aggravate the health situation, sensitizing individuals with common proteins throughout the year. Dhyani et al. [45], has documented the cross-reactivity among P. juliflora, Ailanthus excelsa, and Senna siamea pollen components, and with Holoptelea integrifolia, Putranjiva roxburghii, and Salvadora persica pollen allergens. Similarly, More et al. [46] used 10-20\% gels to investigate the allergens of P. juliflora in Arizona, USA, and reported Immunoglobulin E (IgE) responses to 59 and $66 \mathrm{kDa}$ proteins in the pollen, wood and wood smoke of P. multiflora. The serum IgE binding to a $66 \mathrm{kDa}$ allergen of P. juliflora pollen extract 
was significantly inhibited by lima bean seed extract and P. juliflora pollen extract. Purified proteins showed a close allergenic relationship with A. excelsa, Senna siamea, and S. persica tree pollens and with Phaseolus lunatus. This cross-reactive purified proteins could, therefore, be used as a representative for multiple pollen/food allergens and may have implications for component-based therapy of allergies [47]. Assarehzadegan et al. [48], found, using SDS-PAGE, that there were several IgE-binding proteins in $P$. juliflora pollen extract with a molecular weight of $10-85 \mathrm{kDa}$. However, a molecular weight of approximately 20 and $66 \mathrm{kDa}$ was the most frequent IgE reactive bands among the patient sera. On the other hand, inhibition experiments revealed high IgE cross-reactivity between P. juliflora and Acacia farnesiana. Thakur [49] reported a 45\% success rate in using both the P. juliflora crude allergen extract and the $20 \mathrm{kDa}$ glycoprotein fraction in human desensitization to Prosopis.

\section{Prosopis juliflora Flowering Phenology and Pollen Attributes}

A number of phenological factors contribute to the allergenic potential of Prosopis and need to be considered for aid in prevention and control, with pollen form flowers being a major issue. Prosopis flowers are small (4-6 mm long), arranged in inflorescences of various sizes and shapes, but generally in cylindrical spike-like racemes with $9.5-16.5 \mathrm{~cm}$ long and 300-400 flowers [50,51]. The inflorescences are arranged in clusters of $2-5$ at the end of the branches [51]. Prosopis trees generally initiate flowering at a young age, in the third or fourth year after germination, but sometiems earlier. First flowering is dependent on optimal growth conditions and can be delayed under drought stress or when growing in very poor soils [9]. Prosopis species produce flowers every year increasing gradually for up to 10-20 years and can be expected to continue at high flowering levels for several decades.

Interestingly, in the native range, $P$. juliflora exhibits different physiological responses to environmental variables, mainly temperature, rainfall and day length [9], so variation in the onset of flowering is present between different populations due to climatic variation. Flowering is also variable within and between trees of the same population [9]. This is crucial to know when issuing precautionary advice to people. In its native range the Prosopis juliflora flowering season varies, with one or two periods of main flower production. It generally coincides with the wet season, from December to February and it is delayed from March to April with a second period from July to September.. Therefore, legume production generally overlaps with the end of the wet season improving seedling establishment or partly cover the dry season, ensuring pod consumption and seed dispersal by feral animals. In the invaded area P. juliflora present multiple different possibilities of flowering, associated not only to climatological conditions but to evolutionary associations, extremely fast, with pollinator insects. In Punjab (India) P. juliflora showed one flowering period from January to May with earlier flowering time period with the increase in the temperature [52,53], but in the ridge of Delhi (India) P. juliflora flowering occurs all year round reaching its peaks in April and September [30]. An almost continuous flowering, all-year-round, was observed in some invaded areas such as Brasil or Haiti [54]. This highlights the importance of seasonality when managing the tree to reduce pollen loads. Importance should be placed on controlling young trees before they flower out of season, but the need to focus on the removal older trees during flowering seasons to reduce pollen release and pollen loads. It also shows that awareness raising about health risks should coincide with flowering times, which differ acorss various invasive ranges.

\subsection{Timing of Flowering and Pollen Production}

There is controversy about time development of flowers in P. juliflora. Styles emerge from most flowers prior to anthesis and flowers remain in this state for some days [9]. Anthesis occurs when flowers are fully open and accessible to pollinators. Flower maturation is variable in the same tree, often lower flowers in the raceme are fully developed than the upper ones that are still immature (acropetal succession). Different maturation periods in the reproductive organs and flower development make P. juliflora plants self-incompatibles. Obligate outcrossing leading to high genetic variability as an evolutionary mechanism for survival in zones with a high variability in rainfall, temperature, and soil 
types. This trait, among others, allows to P. juliflora being an effective plant invader. Furthermore, long periods of asynchronous flower production lead to long periods of pollen release, which can prolong allergy issues.

\subsection{Pollen Morphology, Dispersal Mechanisms and Diurnal Patterns}

Prosopis juliflora presents tri-zono-colporate pollen grains, isopolar, and radio-symetric. Triangular in polar view, angulaperturate; elliptic in equatorial view, oblate. Medium size $(\mathrm{P}=23 \mu \mathrm{m}, \mathrm{E}=30 \mu \mathrm{m}$, non-acetolised). Apertures 3, composed by colpus + porus, situated in the equatorial zone. Exine $1.5-2 \mu \mathrm{m}$ thickness with sexine lightly thicker than nexine. Tectum complete and infratectum columellar, with thin and hardly visible columellae with a light microscope. Surface psilate-perforated, lacking of supratectal elements. These characters are valuable in assisting the identification of taxa groups that can be used to differentiate between different species in the Prosopis genus and to identify tree pollens causing allergies. According to Sajjad et al. [55], the flowers of $P$. juliflora are self-incompatible, entomophilous, depending on insects for seed setting. This entomophilia is extremely generalized, with 77 insect visitors being reported in India. Hymenoptera (bees and wasps) and Diptera (flies) are the main visitors, attracted by the abundant pollen production and small quantities of concentrated nectar. Prosopis juliflora flowers exhibit exerted stamens, its pollen grains present a secondary anemophily and can easily pass into the atmosphere and become airborne. So, after gravitational deposition, pollens can deposit on many sufraces including the respiratory tract of humans thus causing allergies, but also in may other areas where they can later be disturbed and inhaled, as indicated in in fossil samples [39].

\section{Impact of Climate Change on P. juliflora Pollen Allergy}

Several factors including climate change are likely to affect pollen production, release and ultimately allergic disease [56]. Health professionals have shown that allergenic diseases will generally increase under climate change $[57,58]$. Due to higher atmospheric temperatures, local conditions in many areas will also become dryer which would facilitate the production of more pollens (e.g., for Prosopis), especially in arid and semi-arid areas. This can cause further negative consequences for the local inhabitants $[59,60]$. The patterns of sensitization to pollens depend on exposure risks which vary depending on the environmental characteristics (climate, geography, vegetation, etc.) of a given region, making predictions of allergy occurrence difficult. It is expected that climate change would exacerbate the prevailing stress in Arab Gulf countries [61].

$\mathrm{CO}_{2}$ is an important factor, but not the only one, affecting the abundance of species and their flowering under future climate change scenarios. The increase in $\mathrm{CO}_{2}$ will improve tree growth allowing them to develop faster andproduce more pollens and thus increasing the overall pollen load and the threat of allergies [62]. Plant species are expected to undertake spatial (poleward and upward) shifts in ranges [63] that will influence the abundance and distribution of allergenic plants and invasive species like Prosopis in particular [64,65]. Furthermore, several environmental pollutants, especially diesel engine exhaust particles, have been considered as significant pollen allergen releasing factors in the air. These particles contain minerals such as silica, iron, aluminum, magnesium, manganese, Sulphur, and others, which faciliates allergenicity. According to Knox et al. [66], pollen allergens associated with carbon particles from diesel engine fumes (DECP) would concentrate many allergic molecules in a single particle, and consequently, serious health risks might arise from this situation. Lately, to a lesser extent, but in addition to pollen exposure, the burning of $P$. juliflora wood will contibute to climate change, and its resulting smoke may be another source of exposure to some of these allergens [46,67]. 


\section{Othere Imapcts of Prosopis for Human Health and Well-Being}

\subsection{Physical Injuries for Humans}

There are a number of studies where communities highlight the Prosopis tree thorns that cause flesh related injuries, apparently resulting in some human fatalities $[11,12,68]$. Prosopis thorns are very hard and long, and when they pierce the skin they go deep into the flesh where the tip often breaks off. Deep pricks from Prosopis thorns are known to cause itching, and ounds can lead to lameness and amputation due to severe infection. For example, Mwangi and Swallow [12], describe how villages in Kenya are negatively impacted by "sharp, strong, and poisonous thorns of Prosopis". This is also mirrored in a different region in Kenya [68], Eritrea [69], Ethiopia [70], South Africa [7], and Sudan [71].. There are records of hospitalization as a result of Prosois injuries and a few cases of death from infection [68]. Laxén [71], also reports cases of amputations due to infections as a result of Prosopis thorns in Sudan, with other similar complaints from other regions such as South Africa $[6,7]$. The Prosopis wax also causes irritation following contact with it [72].

\subsection{Prosopis as Consequence of Increased Malaria}

A community in Loboti, Kenya, reported the increased incidence of malaria associated with Prosopis invasions as the biggest negative impact induced by the invasive tree [11,12]. This has recently been verified by Muller et al. [73], who conducted experimental testing in Mali. Prosopis increases the incidence of malaria, as mosquitos feed primarily on tree sap (honeydew) and nectar. Females only need blood to reproduce otherwise they feed on plants and males only feed on plant products [73]. The invasion of Prosopis, therefore, provides more food for mosquitoes resulting in increased populations and consequently more vectors for carrying the malaria disease. The altered microhabitat (increase moisture in the leaf litter, and cooler areas) also might help with mosquito breeding and survival. In the study by Muller et al. [73], Prosopis was removed and resulted in $69.4 \%$ drop in mosquito population density. The proportion of sugar-fed female mosquitoes that potentially carry malaria dropped from $73 \%$ to $15 \%$ having obvious implications for human health.. Linked to these, Maundu et al. [68], highlight that communities reported an increased incidence of green biting flies is higher in areas with dense invasions, and further investigation is needed.

\section{Adverse Health Impacts of Prosopis for Animals}

\subsection{Flesh Wounds}

Like humans, livestock and wild animals also sustain flesh woods from Prosopis thorns which is considerd as a serious issue. It is particular problme when the tough thorns get lodged into the soft tissue in animal hooves sometimes making them lame [68]. The camels are particularly prone as they have soft feet [70]. Thorns have also been mentioned to damage livestock's eyes causing blindness [74]. This impacts animal mobility and health, but also people's livleihoods, partiualrly pastioralists in the arid regions of Africa.

\subsection{Dental Impacts}

Communities in Kenya took the government to court over a range of impacts Prosopis has had on their livelihoods, where a goat was famously brought in as a witness. One of these issues was the dental impacts livestock get as a result of eating Prosopis pods [12].. Livestock get disfigured jaws from chewing the hard Prosopis pods too frequently, often as a result of the tree displacing natural forage sources. In addition to this, the high sugar content in the pods results in tooth decay and loss, which in some cases leads to animals starving to death [11,12]. This is mirrored in Maundu et al. [68], where photos of dental impacts can also be seen. Similarly, the heavy consumption of pods by camels results in the loss of teeth affecting their overall feeding capacity and health [75]. 


\subsection{Denervation Atrophy}

When livestock consumes more than $20 \%$ Prosopis in their diet (which is common as it displaces native grazing species) they become prone to a disease called denervation atrophy [76]. Denervation atrophy is a motor neuron disease that impacts natural physiological functioning. This disease is locally known as "armeku" in Afar, Ethiopia, and has had a substantial negative effect on livestock health and thus local livelihoods in the area [77,78]. This has been confirmed by Silva et al. [79], who identified the presence of toxic alkaloids (juliprosopine and juliprosine) in the Prosopis leaves that can be responsible for neurotoxic damage in animals after consumption.

\subsection{Digestive Effects}

The cellulose present in the pods can cause serious problems to the animal's digestive systems. In particular, overconsumption of pods can depress rumen bacterial cellulose activity and might induce a permanent impairment of digestion and eventualy mortality [80,81]. If eaten too much by cattle and goats Prosopis can result in diarrhea and sickness, as highlighted by local villagers in Kenya [68]. This is linked to the high tannin contents of Prosopis leaves [12,82,83]. It has also been documented that the consumption of Prosopis leaves by camels can cause diarrhea and sometimes constipation [82]. Furthermore, villagers in Kenya mentioned that Prosopis seeds get stuck within animal rumens resulting in their ill-health [68]. The seeds and their hard coating are not broken down well during digestion, and if too many pods are eaten they result in blockages and constipation. In Botswana there are reports of death of livestock after eating Prosopis most likely due to digestive tract issues [84].

\section{Conclusions}

Invasive Prosopis juliflora is a source of highly allergenic pollen grains which induces serious allergic reactions and asthma. Thorns cause flesh injuries and infections, and the high densities of invasive of trees, and the sap contained, leads to increased the prevalence of malaria. For animals, Prosopis causes flesh injuries, tooth decay, gastro internal issues, and neurological disorders all of which can lead to mortality. This can negatively affect farming communities' livelihoods. We highlight that the health threats due to P. juliflora in the Arabian Peninsula and Africa has serious negative consequences. As a result of this evidence and other negative social-ecological effects caused by this invasive tree genus (see Shackleton et al., 2014) [6], control actions need to be better implemented at international, national, and regional levels to reduce theses negative effects. This is particularly important when one considers possible range shifts, changes in flowering phenology and increases in the amount of pollen production and allergenic potency, as well as increased invasion densities and competitive ability of Prosopis that could be brought about by changes in climate.

Author Contributions: M.I.H. and A.E.-K. proposed the idea of the work, participated in the review and preparation of the manuscript. M.I.H, R.T.S., M.D.M.T.P., A.E.-K., and L.G. screened, selected, and reviewed the literature, and help in the manuscript drafting. R.T.S. provided several texts for the manuscript. All authors have read and agreed to the published version of the manuscript.

Funding: This study was partially supported by a research project (ID: 150428) funded by the Sharjah Research Academy and Research Office, University of Sharjah.

Acknowledgments: The author would like to thank Vice Chancellor for Research, University of Sharjah, UAE for partial funding.

Conflicts of Interest: The authors declare no conflict of interest.

\section{References}

1. Kolar, C.S.; Lodge, D.M. Progress in invasion biology: Predicting invaders. Trends Ecol. Evol. 2001, 16, 199-204. [CrossRef] 
2. Leru, P.M.; Eftimie, A.M.; Thibaudon, M. First allergenic pollen monitoring in Bucharest and results of three years collaboration with European aerobiology specialists. Rom. J. Int. Med. 2018, 56, 27-33. [CrossRef] [PubMed]

3. Barbier, E.B.; Knowler, D.; Gwatipedza, J.; Reichard, S.H. An economic analysis of the invasive plant problem associated with the horticulture industry in North America. Invasive Plant Ecol. 2013, 259. [CrossRef]

4. Shackleton, R.T.; Witt, A.B.; Piroris, F.M.; van Wilgen, B.W. Distribution and socio-ecological impacts of the invasive alien cactus Opuntia stricta in eastern Africa. Biol. Invasions 2017, 19, 2427-2441. [CrossRef]

5. Castro-Díez, P.; Vaz, A.S.; Silva, J.S.; Van Loo, M.; Alonso, Á.; Aponte, C.; Bayón, Á.; Bellingham, P.J.; Chiuffo, M.C.; DiManno, N.; et al. Global effects of non-native tree species on multiple ecosystem services. Biol. Rev. 2019, 94, 1477-1501. [CrossRef] [PubMed]

6. Shackleton, R.T.; Le Maitre, D.C.; Pasiecznik, N.M.; Richardson, D.M. Prosopis: A global assessment of the biogeography, benefits, impacts and management of one of the world's worst woody invasive plant taxa. AoB Plants 2014, 6, 1-18. [CrossRef] [PubMed]

7. Shackleton, R.T.; Le Maitre, D.C.; Richardson, D.M. Stakeholder perceptions and practices regarding Prosopis (mesquite) invasions and management in South Africa. AMBIO 2015, 44, 569-581. [CrossRef] [PubMed]

8. Burkart, A. A monograph of the genus Prosopis (Leguminosae subfam. Mimosoideae). (Part 1 and 2). Catalogue of the recognized species of Prosopis. J. Arnold Arbor. 1976, 57, 450-525.

9. Pasiecznik, N.M.; Felker, P.; Harris, P.J.; Harsh, L.; Cruz, G.; Tewari, J.C.; Cadoretm, K.; Maldonado, L.J. The Prosopis Juliflora-Prosopis Pallida Complex: A Monograph; HDRA: Coventry, UK, 2001; Volume 172.

10. Elfadl, M.A.; Luukkanen, O. Field studies on the ecological strategies of Prosopis juliflora in a dryland ecosystem 1: A leaf gas exchange approach. J. Arid Environ. 2006, 66, 1-15. [CrossRef]

11. Mwangi, E.; Swallow, B. Invasion of Prosopis juliflora and Local Livelihoods: Case Study from the Lake Baringo Area of Kenya; ICRAF Working Paper-no. 3; World Agroforestry Centre: Nairobi, Kenya, 2005.

12. Mwangi, E.; Swallow, B. Prosopis juliflora invasion and rural livelihoods in the Lake Baringo area of Kenya. Conserv. Soc. 2008, 6, 130-140.

13. Mishra, A.; Sharma, S.D.; Gupta, M.K. Soil rehabilitation through afforestation: Evaluation of the performance of Prosopis juliflora, Dalbergia sissoo and Eucalyptus tereticornis plantations in a sodic environment. Arid Land Res. Manag. 2003, 17, 257-269. [CrossRef]

14. Tegegn, G. Experiences on Prosopis Management Case of Afar Region; FARM-Africa: London, UK, 2008.

15. Hunziker, J.-H.; Saidman, B.O.; Naranjo, C.A.; Palacios, R.A.; Poggio, L.; Burghardt, A.D. Hybridization and genetic variation of Argentina species of Prosopis. For. Ecol. Manag. 1986, 16, 301-316. [CrossRef]

16. Landeras, G.; Alfonso, M.; Pasiecznik, N.M.; Harris, P.J.C.; Ramirez, L. Identification of Prosopis juliflora and Prosopis pallida accessions using molecular markers. Biodivers. Conserv. 2006, 15, 1829-1844. [CrossRef]

17. Sherry, M.; Smith, S.; Patel, A.; Harris, P.; Hand, P.; Trenchard, L.; Henderson, J. RAPD and microsatellite transferability studies in selected species of Prosopis (section Algarobia) with emphasis on Prosopis juliflora and P. pallida. J. Genet. 2011, 90, 251-264. [CrossRef]

18. Akrimi, N. Prosopis in Tunisia. In The Current State of Knowledge on Prosopis juliflora; Habit, M.A., Saavedra, J.C., Eds.; FAO: Rome, Italy, 1990; pp. 147-151.

19. El-Keblawy, A.; Al-Rawai, A. Impacts of the invasive exotic Prosopis juliflora (Sw.) D.C. on the native flora and soils of the UAE. Plant Ecol. 2007, 190, 23-35. [CrossRef]

20. El-Keblawy, A.; Abdelfatah, M.A. Impacts of native and invasive exotic Prosopis congeners on soil properties and associated flora in the arid United Arab Emirates. J. Arid Environ. 2014, 100-101, 1-8. [CrossRef]

21. Hussain, M.I.; El-Keblawy, A.; Mitterand Tsombou, F. Leaf age, canopy position, and habitat affect the carbon isotope discrimination and water-use efficiency in three $C_{3}$ Leguminous Prosopis species from a hyper-arid climate. Plants 2019, 8, 402. [CrossRef]

22. Thomas, J.; El-Sheikh, M.A.; Alfarhan, A.H.; Alatar, A.A.; Sivadasan, M.; Basahi, M.; Al-Obaid, S.; Rajakrishnan, R. Impact of alien invasive species on habitats and species richness in Saudi Arabia. J. Arid Environ. 2016, 127, 53-65. [CrossRef]

23. Tourenq, C.; Shuriqi, M.K. Snapshot on introduced invasives in a desertic country, the United Arab Emirates. Aliens 2010, 30, 49-51.

24. Ahmad, R.; Ismail, S. Use of Prosopis in Arab/Gulf states including possible cultivation with saline water in deserts. In Prosopis: Semi-Arid Fuelwood and Forage Tree. Building Consensus for the Disenfranchised. Kingsville; Felker, P., Moss, J., Eds.; Center Semi-Arid Forest Resources: Kingsville, TX, USA, 1996; pp. 1.41-1.52. 
25. Simpson, B.B.; Neff, J.L.; Moldenke, A.R. Prosopis flowers as a resource. In Mesquite: Its Biology in Two Desert Scrub Ecosystems; Simpson, B.B., Ed.; Dowden, Hutchinson and Ross: Stroudsburg, PA, USA, 1977.

26. Ordman, D. Prosopis tree as a cause of seasonal hay fever and asthma in South Africa. S. Afr. Med J. 1950, 33, 12.

27. Bieberdord, F.W.; Swinny, B. Mesquite and related plants in allergy. Ann. Allergy 1952, 10, 720.

28. Shivpuri, D.N.; Parkash, D. A study in allergy to Prosopis juliflora (Kabuli keekar). Ann. Allergy 1967, 25, 643-648. [PubMed]

29. Novey, H.A.; Roth, M.; Wells, I.D. Mesquite pollen: An aeroallergen in asthma and allergic rhinitis. J. Allergy Clin. Immun. 1977, 59, 359-363. [CrossRef]

30. Thakur, I.S. Fractionation and analysis of allergenicity of allergens from Prosopis juliflora pollen. Int. Arch. Allergy Immunol. 1989, 90, 124-129. [CrossRef] [PubMed]

31. Lucas, S.K.; Buckley, C.E. Quantitative studies of cutaneous hypersensitivity. The prevalence of epicutaneous flare reactions to allergenic pollen extracts. J. Allergy Clin. Immunol. 1989, 84, 465-474. [CrossRef]

32. Singh, A.B.; Mathur, C. An aerobiological perspective in allergy and asthma. Asia Pac. Allergy 2012, 2, 210-222. [CrossRef]

33. Perveen, A.; Zeb, S.; Khan, M.; Qaiser, M. Seasonal fluctuations of airborne pollen grains count and its correlation with climatic factors from Khairpur, Sindh, Pakistan. Pak. J. Bot. 2014, 46, 299-306.

34. Al-Frayh, A.; Hasnain, S.M.; Gad-elRab, M.O.; Al-Turki, T.; Al-Mobeireek, K.; Al-Sedairy, S.T. Human sensitization to Prosopis juliflora antigen in Saudi Arabia. Ann. Saudi Med. 1999, 19, 331-336. [CrossRef]

35. Hawke, P.R.; Meadows, M.E. Winter airspora spectra and meteorological conditions in Cape Town, South Africa. Grana 1989, 28, 187-192. [CrossRef]

36. Shackleton, S.E.; Shackleton, R.T. Local knowledge regarding ecosystem services and disservices from invasive alien plants in the arid Kalahari, South Africa. J. Arid Environ. 2018, 159, 22-33. [CrossRef]

37. Latorre, F.; Perez, C.F. One year of airborne pollen sampling in Mar del Plata (Argentina). Grana 1997, 36, 49-53. [CrossRef]

38. Ezeamuzie, C.I.; Thomson, M.S.; Al-Ali, S.; Dowaisan, A.; Khan, M.; Hijazi, Z. Asthma in the desert: Spectrum of the sensitizing aeroallergens. Allergy 2000, 55, 157-162. [CrossRef] [PubMed]

39. Davis, O.K. Climate and vegetation patterns in surface samples from arid western U.S.A.: Application to Holocene climatic reconstructions. Palynology 1995, 19, 97-120. [CrossRef]

40. Killian, S.; McMichael, J. The human allergens of mesquite (Prosopis juliflora). Clin. Mol. Allergy 2004, 2, 8. [CrossRef] [PubMed]

41. Dhyani, A.; Arora, N.; Gaur, S.N.; Jain, V.K.; Sridhara, S.; Singh, B.P. Analysis of IgE binding proteins of mesquite (Prosopis juliflora) pollen and cross-reactivity with predominant tree pollens. Immunobiology 2006, 211, 733-740. [CrossRef] [PubMed]

42. Al-Soqeer, A.A.; Alsubaie, Q.D.; Motawei, M.I.; Mousa, H.M.; Ahmed, M.; Abdel-Salam, A.M. Isolation and identification of allergens and biogenic amines of Prosopis juliflora genotypes. Electron. J. Biotechnol. 2017, 30, 24-32. [CrossRef]

43. Dhyani, A.; Singh, B.P.; Arora, N.; Jain, V.K.; Sridhara, S. 2008. A clinically relevant major cross-reactive allergen from mesquite tree pollen. Eur J. Clin. Invest. 2008, 38, 774-781. [CrossRef]

44. Thakur, I.S.; Sharma, J.D. Isolation and characterization of allergens of Prosopis juliflora pollen grains. Biochem. Int. 1985, 11, 903-912.

45. Dhyani, A.; Arora, N.; Jain, V.K.; Sridhara, S.; Singh, B.P. Immunoglobulin E (IgE)-mediated cross-reactivity between mesquite pollen proteins and lima bean, an edible legume. Clin. Exp. Immunol. 2007, 149, 517-524. [CrossRef]

46. More, D.; Whisman, L.; Whisman, B.; Jordan-Wagner, D. Identification of specific IgE to mesquite wood smoke in individuals with mesquite pollen allergy. J. Allergy Clin. Immunol. 2002, 110, 814-816. [CrossRef]

47. Neudecker, P.; Schweimer, K.; Nerkamp, J.; Scheurer, S.; Vieths, S.; Sticht, H.; Rösch, P. Allergic cross-reactivity made visible: Solution structure of the major cherry allergen Pru av 1. J. Biol. Chem. 2001, 276, 22756-22763. [CrossRef] [PubMed]

48. Assarehzadegan, M.A.; Khodadadi, A.; Amini, A.; Shakurnia, A.H.; Marashi, S.S.; Ali-Sadeghi, H.; Zarinhadideh, F.; Sepahi, N. Immunochemical Characterization of Prosopis Juliflora pollen allergens and evaluation of cross-reactivity pattern with the most allergenic pollens in tropical areas. Iran. J. Allergy Asthma Immunol. 2015, 14, 74-82. [PubMed] 
49. Thakur, I.S. Purification and characterization of the glycoprotein allergen from Prosopis juliflora pollen. Biochem. Intern. 1991, 23, 449-459.

50. Díaz Celis, A. Los Algarrobos; CONCYTEC: Lima, Peru, 1995.

51. Zaitoun, S.; Al-Ghzawi, A.A.; Samarah, N.; Mullen, R. Pod production of Prosopis juliflora (Sw.) DC. As affected by supplementary and honeybee pollination under arid conditions. Acta Agric. Scand. Sect. B 2009, 59, 349-356.

52. Kaur, G.; Singh, B.P.; Nagpal, A.K. Phenology of some phanerogams (trees and shrubs) of Northwestern Punjab, India. J. Bot. 2013, 2013, 712405. [CrossRef]

53. Kaur, R.; Gonzáles, W.L.; Llambi, L.D.; Soriano, P.J.; Callaway, R.M.; Rout, M.E.; Gallaher, T.J. Community impacts of Prosopis juliflora invasion: Biogeographic and congeneric comparisons. PLoS ONE 2012, 7, e44966. [CrossRef]

54. Silva, S. Prosopis juliflora (Sw) DC Brazil. In The Current State of Knowledge on Prosopis juliflora; Habit, M.A., Saavedra, J.C., Eds.; FAO: Rome, Italy, 1988.

55. Sajjad, A.; Saeed, S.; Bashir, M.A. Spatial variation in pollinator communities and reproductive performance of Prosopis juliflora (Fabaceae). J. Pollinat. Ecol. 2012, 8, 59-66. [CrossRef]

56. Smith, K.R.; Woodward, A.; Campbell-Lendrum, D.; Chadee, D.D.; Honda, Y.; Liu, Q.; Olwoch, J.M.; Revich, B.; Sauerborn, R.; Aranda, C.; et al. Human health: Impacts, adaptation, and co-benefits. In Climate Change 2014: Impacts, Adaptation, and Vulnerability Part. A: Global and Sectoral Aspects Contribution of Working Group II to the Fifth Assessment Report of the Intergovernmental Panel on Climate Change; Field, C.B., Barros, V.R., Dokken, D.J., Mach, K.J., Mastrandrea, M.D., Bilir, T.E., Chatterjee, M., Ebi, K.L., Estrada, Y.O., Genova, R.C., et al., Eds.; Cambridge University Press: Cambridge, UK, 2014; pp. 709-754.

57. Bielory, L.; Lyons, K.; Goldberg, R. Climate change and allergic disease. Curr. Allergy Asthma Rep. 2012, 12, 485-494. [CrossRef]

58. Ziska, L.H.; Makra, L.; Harry, S.K.; Bruffaerts, N.; Hendrickx, M.; Coates, F.; Saarto, A.; Thibaudon, M.; Oliver, G.; Damialis, A.; et al. Temperature-related changes in airborne allergenic pollen abundance and seasonality across the northern hemisphere: A retrospective data analysis. Lancet Planet. Health 2019, 3, e124-e131. [CrossRef]

59. Kim, S.H.; Park, H.S.; Jang, J.Y. Impact of meteorological variation on hospital visits of patients with tree pollen allergy. BMC Public Health 2011, 11, 890. [CrossRef]

60. Beggs, P.J. Environmental allergens: From asthma to hay fever and beyond. Curr. Clim. Chang. Rep. 2015, 1, 176-184. [CrossRef]

61. Immerzeel, P.; Schols, H.A.; Voragen, A.G.J.; de Vries, S.C. Different arabinogalactan proteins are present in carrot (Daucus carota) cell culture medium and in seeds. Physiol. Plant 2004, 122, 181-189. [CrossRef]

62. Wayne, P.; Forster, S.; Connelly, J.; Bazzaz, F.A.; Epstein, P.R. Production of allergenic pollen by ragweed (Ambrosia artemisiifolia L.) is increased in $\mathrm{CO}_{2}$ enriched atmospheres. Ann. Allergy Asthma Immunol. 2002, 88, 279-282. [CrossRef]

63. IPCC. Summary for Policymakers; Parry, M.L., Canziani, O.F., Palutikof, J.P., van der Linden, P., Eds.; Cambridge University Press: Cambridge, UK, 2007.

64. Polley, H.W.; Johnson, H.B.; Mayeux, H.S.; Tischler, C.R.; Brown, D.A. Carbon dioxide enrichment improves growth, water relations and survival of droughted honey mesquite (Prosopis glandulosa) seedlings. Tree Physiol. 1996, 16, 817-823. [CrossRef]

65. Cecchi, L.; D'Amato, G.; Ayres, J.G.; Galan, C.; Forastiere, F.; Forsberg, B.; Gerritsen, J.; Nunes, C.; Behrendt, H.; Akdis, C.; et al. Projections of the effects of climate change on allergic asthma: The contribution of aerobiology. Allergy 2010, 65, 1073-1081. [CrossRef]

66. Knox, R.B.; Suphioglu, C.; Taylor, P.; Desai, R.; Watson, H.C.; Peng, J.L.; Bursill, L.A. Major grass pollen allergen Lol p 1 binds to diesel exhaust particles: Implications for asthma and air pollution. Clin. Exp. Allergy 1997, 27, 246-251. [CrossRef]

67. Johns, R.E.; Lee, J.S.; Agahian, B.; Gibbons, H.L.; Reading, J.C. Respiratory effects of mesquite broiling. J. Occup. Med. 1986, 28, 1181-1184.

68. Maundu, P.; Kibet, S.; Morimoto, Y.; Imbumi, M.; Adeka, R. Impact of Prosopis juliflora on Kenya's semi-arid and arid ecosystems and local livelihoods. Biodiversity 2009, 10, 33-50. [CrossRef] 
69. Bokrezion, H. The Ecological and Socio-Economic Role of Prosopis juliflora in Eritrea. An Analytical Assessment within the Context of Rural Development in the Horn of Africa. Ph.D. Thesis, Pharmazieudd Geowissenschaften der Johannes Gutenberg-Universität Mainz, Mainz, Germany, 2008.

70. Walkie, T.T.; Hoag, D.; Evangelista, P.H.; Luizza, M.; Laituri, M. Is control through utilization a cost-effective Prosopis juliflora management strategy? J. Environ. Manag. 2016, 168, 74-86.

71. Laxén, J. Is Prosopis a Curse of a Blessing?-An Ecological-Economic Analysis of the Invasive Alien Tree Species in Sudan. Ph.D. Thesis, Faculty of Agriculture and Forestry University of Helsinki, Helsinki, Finland, 2007.

72. Sharma, I.K. Ecological and economic importance of Prosopis juliflora in the Indian Thar Desert. J. Taxon. Bot. 1981, 2, 245-248.

73. Muller, G.C.; Junnila, A.; Traore, M.M.; Traore, S.F.; Doumbia, S.; Sissoko, F.; Dembele, S.M.; Schlein, Y.; Arheart, K.L.; Revay, E.E.; et al. The invasive shrub Prosopis juliflora enhances the malaria parasite transmission capacity of Anopheles mosquitoes: A habitat manipulation experiment. Malar. J. 2017, 16, 237. [CrossRef] [PubMed]

74. Grant, W.M.; Schuman, J.S. Toxicology of the Eye: Effects on the Eyes and Visual System from Chemicals, Drugs, Metals and Minerals, Plants, Toxins and Venoms; Also Systemic Side Effects from Eye Medications; Charles C Thomas Publisher: Springfield, IL, USA, 1993; Volume 1.

75. Shimles, A.; Getachew, M. Contemporary Prosopis dilemma: Perception of inhabitants of Sabian Kebele (Goro) towards invasive tree Prosopis juliflora, Eastern Ethiopia. J. Agric. Biotechnol. Sustain. Dev. 2016, 8, 1-6. [CrossRef]

76. Tabosa, I.M.; Riet-Correa, F.; Barros, S.S.; Summers, B.A.; Simões, S.V.D.; Medeiros, R.M.T.; Nobre, V.M.T. Neurohistologic and ultrastructural lesions in cattle experimentally intoxicated with the plant Prosopis juliflora. Vet. Pathol. 2006, 43, 695-701. [CrossRef] [PubMed]

77. Admasu, D. Invasive plants and food security: The case of Prosopis juliflora in the Afar region of Ethiopia. FARM-Afr. IUCN 2008, 1-13.

78. William, K.; Jafri, L. Mesquite (Prosopis juliflora): Livestock grazing, its toxicity and management. J. Biores. Manag. 2015, 2, 7. [CrossRef]

79. Silva, V.D.A.; Pitanga, B.P.S.; Nascimento, R.P.; Cleide, S.; Coelho, P.L.C.; Menezes-Filho, N.; Silva, A.M.M.; de Costa, M.F.D.; El-Bachá, R.S.; Velozo, E.S.; et al. Juliprosopine and Juliprosine from Prosopis juliflora leaves induce mitochondrial damage and cytoplasmic vacuolation on cocultured glial cells and neurons. Chem. Res. Toxicol. 2013, 26, 1810-1820. [CrossRef]

80. Lewis, W.H. Airborne pollen of the Neotropics. Grana 1986, 25, 75-83. [CrossRef]

81. Lewis, W.H.; Elvin Lewis, M.P.F. Medical Botany. Plants Affecting Human Health; Economic Botany; John Wiley \& Sons: Hoboken, NJ, USA, 2004.

82. Abdillahi, A.; Aboud, P.; Kisoyan, K.; Coppock, D.L. Agro-Pastoralists' Wrath for the P. juliflora Tree: The Case of the II Chamus of Baringo District. Pastoral Risk Management Project: Nairobi, Kenya, 2005.

83. Singh, S. Phytochemical analysis of different parts of Prosopis juliflora. Int. J. Curr. Pharm. Res. 2012, 4, 59-61.

84. Mosweu, S.; Munyati, C.; Kabnda, T.; Setshongo, M.; Muzila, M. Prosopis L. invasion in the south-western region of Botswana: The perceptions of rural communities and management options. Nat. Resour. 2013, 4, 496-505.

(C) 2020 by the authors. Licensee MDPI, Basel, Switzerland. This article is an open access article distributed under the terms and conditions of the Creative Commons Attribution (CC BY) license (http://creativecommons.org/licenses/by/4.0/). 